\title{
Development and production of maize as a function of biochar rates
}

\section{Desenvolvimento e produção de milho em função de doses de biocarvão}

\author{
Jacqueline Da Silva Mendes ${ }^{1}$; Lucia Helena Garófalo Chaves ${ }^{2 *}$; Josely Dantas \\ Fernandes ${ }^{3}$; Gilvanise Alves Tito3; Hugo Orlando Carvallo Guerra ${ }^{2}$; Laysa \\ Gabryella de Souza Laurentino4; Gustavo Tomio Magalhaes Kubo4; Edilma \\ Rodrigues Bento Dantas ${ }^{5}$; Yuri Santos Silva4; Luan Dantas de Oliveira ${ }^{4}$
}

\section{Highlights}

Biochar was produced from poultry litter.

Biomass and ear production were influenced by biochar application.

The recommended rate for the best results is $6.4 \mathrm{t} \mathrm{ha}^{-1}$.

\section{Abstract}

Poultry litter biochar has shown to be promising in crop development and production. On this basis, this study was developed to investigate the influence of increasing rates of poultry litter biochar on the growth and production of maize hybrid BRS 2022. The experiment was laid out in a completely randomized design with six biochar rates $\left(0,2.0,4.0,6.1,8.1\right.$ and $\left.10.1 \mathrm{t} \mathrm{ha}^{-1}\right)$ and four replicates. Plots consisted of pots with a volume of $20 \mathrm{dm}^{3}$, with one plant each. The following variables were evaluated at 83 days after sowing: plant height; first-ear insertion height; stem diameter; number of leaves; leaf area; internode length and number; stem, leaf and total dry weights; ear weight; grain weight per plant; 1000-grain weight; and ear length and diameter. Biochar application influenced plant height; first-ear insertion height; stem diameter; leaf area; internode length; and stem, leaf and total dry weights, having a positive impact in increasing in ear weight, grain weight per plant, 1000-grain weight and ear length and diameter. For the conditions in which the experiment was conducted, the recommended biochar rate to obtain the best results is $6.4 \mathrm{t} \mathrm{ha}^{-1}$.

Key words: Zea mays L. Growth and production. Poultry litter.

1 Dra Researcher, Agricultural Engineering Department, Universidade Federal de Campina Grande, UFCG, Campina Grande, PB, Brazil. E-mail: jacquelinemendes@gmail.com

2 Full Profs., Agricultural Engineering Department, UFCG, Campina Grande, PB, Brazil. E-mail: Ingarofalo@hotmail. com; hugo carvallo@hotmail.com

${ }^{3}$ Postdoctoral Students, Agricultural Engineering Department, UFCG, Campina Grande, PB, Brazil. E-mail: gilvanisetito@yahoo.com.br; joselysolo@yahoo.com.br

${ }^{4}$ Students of the Postgraduate Program in Agricultural Engineering, UFCG, Campina Grande, PB, Brazil. E-mail: laysaagabryella@live.com; tomio_16@hotmail.com; yurieaac@gmail.com; luan.dantas@outlook.com

${ }_{5}^{5}$ Dra Researcher, Civil Engineering Department, UFCG, Campina Grande, PB, Brazil. E-mail: edilma.dantas@hotmail.com

* Author for correspondence

Received: June 17, 2021 - Approved: Sept. 30, 2021 


\section{Resumo}

Biocarvão da cama de aviário tem se mostrado promissor no desenvolvimento e produção de culturas. Dessa forma, o objetivo com esse trabalho foi o de avaliar a influência de doses crescentes de biocarvão de cama de aviário no crescimento e na produção do milho híbrido BRS 2022. O experimento foi conduzido em delineamento inteiramente casualizado, com quatro repetições, sendo seis doses de biocarvão $(0 ; 2,0$; 4,$0 ; 6,1 ; 8,1$ e 10,1 tha-1 $^{-1}$ e as parcelas constituídas por uma planta por vaso com volume de $20 \mathrm{dm}^{3}$. Aos 83 dias após a semeadura do milho foram avaliadas as seguintes variáveis: alturas da planta e da inserção da primeira espiga, diâmetro do colmo, número de folhas, área foliar, comprimento e número de internódios, fitomassa seca de colmos, de folhas e total, massa de espiga, de grãos por planta e de 1000 grãos e comprimento e diâmetro de espigas. A aplicação do biocarvão influenciou na altura da planta e da inserção da primeira espiga, diâmetro do colmo, área foliar, comprimento de internódios, fitomassa seca de colmo, de folhas e total, refletindo positivamente no aumento das massas de espiga, de grãos por planta, de 1000 grãos, comprimento e diâmetro de espigas. Para as condições em que o experimento foi conduzido a dose de biocarvão recomendada para obtenção dos melhores resultados é de 6,4 t ha-1.

Palavras-chave: Zea mays L. Crescimento e Produção. Cama de aviário.

\section{Introduction}

Biochar has been used as a soil conditioner, as it reduces acidity and $\mathrm{Al}$ availability; increases $\mathrm{pH}$ and nutrient availability to plants ( $P$ and $K$, mainly); and influences the physical and water properties of the soil, increasing the field capacity, wilting point and available water (Mendes et al., 2021; Chaves et al., 2020). In addition to adding carbon to the soil, biochar also delays its return to the atmosphere in the form of $\mathrm{CO} 2$ (Tito, Fernandes, Chaves, Guerra, \& Dantas, 2021).

Biochar is a solid high-carbon material derived from a process called pyrolysis (Tomczyk, Sokołowska, \& Boguta, 2020). Its chemical characteristics vary depending on the conditions of this process, especially temperature. At high temperatures, the chemical composition of biochar is more similar to that of graphite, whereas biochar produced at low temperatures is closer to the original raw material, with a high content of volatile materials (Fernandes et al., 2020). According to Spokas et al. (2011), these volatile materials contribute to the immobilization of nitrogen and reduction of microbial activity, negatively affecting plant growth. In their study, Revell, Maguire and Agblevor (2012) found that the application of low-dose poultry litter biochar increased lettuce germination by almost 50\%, but became toxic at rates greater than $2.5 \%$, likely due to the toxicity of soluble salts present in it. The effects of biochars on crop development have not yet been widely discussed due to the large variability between different types of carbonized materials. Therefore, responses are diverse, with many studies showing positive effects, others negative results and others inconsistent outcomes (Agboola \& Moses, 2015; Biederman \& Harpole, 2013).

Liu et al. (2013) observed an average increase of $11 \%$ in the yield of crops treated with biochar, highlighting the $30 \%$ increase 
in legumes, $29 \%$ in leafy vegetables and $14 \%$ in grasses. As stated by these researchers, biochar rates below $30 \mathrm{t} \mathrm{ha}^{-1}$ provided the best results. Furtado and Chaves (2018) used poultry litter biochar in the sunflower crop and observed marked increases in the growth rates and yield of this crop. After comparing the effect of poultry litter and biochar from this biomass on the improvement of soil acidity and the growth of maize, Masud et al. (2020) concluded that biochar was more efficient in correcting soil acidity, which provided greater nutrient absorption by maize plants.

Maize (Zea mays L.), one of the main cereal crops commonly grown in Brazil, is an essential part of food supply for humans, animal feed and raw materials for some agribusinesses (Pissinati, Oliveira, Pissinati, \& Moreira, 2013). Based on maize genetics research, an early-cycle, double hybrid was developed: BRS 2022, which is recommended for rainy- and dry-season crops and suitable for low investment agriculture, combining good yields with good tolerance to lodging and breakage (Pacheco et al., 2009). On the other hand, in the state of Paraíba, Brazil, a large number of small farmers have been associated with big poultry companies, which started to produce large volumes of poultry litter, whose transformation into biochar represents an economic alternative for these producers. According to the 2017 Agricultural Census (IBGE), the poultry flock in the state exceeded 12 million head, raised in 99,545 establishments.

Focusing on this scenario, the present study proposes to investigate the growth and production of maize hybrid BRS 2022 using poultry litter biochar as an alternative fertilizer source.

\section{Material and Methods}

The experiment was conducted in an agricultural greenhouse made of transparent polyethylene, belonging to the Academic Unit of Agronomic Engineering of the Center for Technology and Natural Resources at the Federal University of Campina Grande (UFCG), located in Campina Grande - PB, Brazil. The greenhouse dimensions were $4 \times 8 \times 3 \mathrm{~m}$ (width, length and height). Samples of the soil, classified as dystric GrayUltisol, were collected in the arable layer (0-0.2 $\mathrm{m}$ depth), in the municipality of Lagoa Seca - PB (0709'22.42' S; 3552'09.64" W) for the experiment. These samples were characterized chemically according to Teixeira, Donagemma, Fontana and Teixeira (2017), which revealed the following properties: $\mathrm{pH}\left(\mathrm{H}_{2} \mathrm{O}\right)=5.35$; organic carbon $=18.8 \mathrm{~g} \mathrm{~kg}^{-1} ; \mathrm{P}=1.27 \mathrm{mg} \mathrm{kg}^{-1}$ and in cmolc kg-1: $\mathrm{Ca}=2.78 ; \mathrm{Mg}=1.26 ; \mathrm{Na}=0.11 ; \mathrm{K}=$ $0.17 ; \mathrm{H}+\mathrm{Al}=3.27$ and $\mathrm{CEC}=7.59$.

The biochar used in this study was produced in the Irrigation and Salinity Laboratory - LIS at UFCG, from poultry litter resulting from the farming of broiler chickens, under slow pyrolysis at $350{ }^{\circ} \mathrm{C}$ for $3 \mathrm{~h}$ in a muffle oven. Analysis of the material revealed following chemical attributes: $\mathrm{pH}=9.44 ; \mathrm{EC}=$ $7.33 \mathrm{dS} \mathrm{m}{ }^{-1} ; \mathrm{P}_{2} \mathrm{O}_{5}=4.08 \% ; \mathrm{K}_{2} \mathrm{O}=4.35 \% ; \mathrm{Ca}=$ $5.04 \% ; \mathrm{Mg}=1.28 \% ; \mathrm{S}=0.41 \% ; \mathrm{Fe}=0.72 \% ; \mathrm{Mn}$ $=0.05 \% ; \mathrm{Cu}=0.01 \% ; \mathrm{Zn}=0.05 \% ; \mathrm{B}=0.01 \%$; organic carbon $=42.22 \%$; and $\mathrm{C} / \mathrm{N}=18.76$.

The experiment was laid out in a completely randomized design with six treatments and four replicates, totaling 24 experimental units. Treatments corresponded to the application of increasing biochar rates $\left(0.00,2.0,4.0,6.1,8.1\right.$ and $\left.10.1 \mathrm{t} \mathrm{ha}^{-1}\right)$ for the cultivation of maize (Zea mays L.) hybrid 
BRS 2022. These rates corresponded to twice the amounts needed to raise the soil base saturation $63,69,75,81$ and $87 \%$, respectively, which were calculated based on calcium carbonate (Relative Total Neutralizing Value, RTNP, 100\%). This was done because the TRNP of biochar is not known.

Plastic containers with a capacity of $20 \mathrm{dm}^{3}$, filled with approximately $23 \mathrm{~kg}$ of soil, were used for the experiment. After incorporating the biochar rates, according to the treatments, the soil was irrigated until reaching $90 \%$ of field capacity (FC), to ensure the effectiveness of the seed germination seedling development processes. Sowing was carried out by distributing three seeds of BRS 2022 maize into each pot equidistantly, at a depth of $0.05 \mathrm{~m}$. After germination, around 10 days after sowing, thinning was performed to leave one plant per experimental unit.

Drip irrigation was applied with an Arduino MEGA2560 system, which features sensors that measure the temperature of the environment and soil moisture (hygrometer). With real-time readings, the irrigation system was activated whenever the soil moisture was below $70 \%$ of FC and turned off when it reached $90 \%$ of $\mathrm{FC}$.

The growth and production variables evaluated at the end of the experiment (83 days after sowing) were plant height (cm); firstear insertion height $(\mathrm{cm})$; stem diameter $(\mathrm{mm})$; number of leaves; leaf area $\left(\mathrm{m}^{2}\right)$; internode length $(\mathrm{cm})$ and number; stem, leaf and total (stems + leaves + ears) dry biomass (g); ear weight (g); grain weight per plant (g); 1000-grain weight (g); and ear length and diameter (cm). The biomasses and ears were oven-dried at $65^{\circ} \mathrm{C}$, under forced ventilation, until reaching a constant weight.

Once the assumptions of normality (Shapiro Wilk's test) and homogeneity (Bartlett's test) were met, the data were subjected to analysis of variance with the significance level determined by the $F$ test at $5 \%$ probability. The effect of biochar rates was analyzed using polynomial regression, in SISVAR statistical software, following Ferreira (2011).

\section{Results and Discussion}

Based on the variance of the growth and biomass variables (Table 1), the biochar rates had a significant effect on plant height; first-ear insertion height; stem diameter; leaf area; internode length; and stem, leaf and total (stem + leaves + ears) dry biomasses. The other evaluated traits showed no significant effects. 
Table 1

Summary of analysis of variance for growth parameters and biomass of BRS 2022 maize as according to biochar rates

\begin{tabular}{|c|c|c|c|c|c|c|c|c|c|c|c|}
\hline \multirow{2}{*}{ SV } & \multirow{2}{*}{ DF } & \multicolumn{10}{|c|}{ Mean square } \\
\hline & & PH & FEIH & SD & NL & LA & INL & NIN & $\mathrm{SDB}^{(1)}$ & $\operatorname{LDB}^{(2)}$ & $\mathrm{TDB}^{(3)}$ \\
\hline Rate & 5 & $2355.7^{* *}$ & $784.3^{* *}$ & $20.8^{* *}$ & $0.64^{\mathrm{ns}}$ & $7 e^{-3 *}$ & $16.3^{\star *}$ & $0.82^{\text {ns }}$ & $3.92 \mathrm{e}^{4 * *}$ & $1.02 \mathrm{e}^{4 * \star}$ & $5,69 e^{9 * *}$ \\
\hline Linear & 1 & $5585.4^{* *}$ & $2005.3^{* *}$ & $86.3^{* *}$ & - & $2.4 \mathrm{e}^{-2 \star *}$ & $42.63^{* *}$ & - & $1.34 \mathrm{e}^{5 * *}$ & $2.79 \mathrm{e}^{4 * *}$ & $1,68 e^{10 * *}$ \\
\hline Quadratic & 1 & $1559.7^{*}$ & $274.4^{\text {ns }}$ & $6.7^{\mathrm{ns}}$ & - & $1.6 e^{-2 *}$ & $14.03^{*}$ & - & $4.20 \mathrm{e}^{4 * *}$ & $1.71 e^{4 * *}$ & $8,35 e^{9 * *}$ \\
\hline Deviation & 3 & $1544.5^{*}$ & $547.2^{*}$ & $3.7^{\mathrm{ns}}$ & - & $1 e^{-4 n s}$ & $8.33^{\text {ns }}$ & - & $6.65 \mathrm{e}^{3 \mathrm{~ns}}$ & $2.08 e^{3 n s}$ & $1,08 e^{9 * *}$ \\
\hline Error & 18 & 305.7 & 145.3 & 1.7 & 0.50 & 0.002 & 2.9 & 0.63 & 3176.0 & 1320.2 & $1,92 e^{8}$ \\
\hline CV (\%) & & 8,59 & 13.4 & 7.37 & 5.92 & 14.85 & 11.59 & 11.63 & 22.0 & 22.29 & 19.66 \\
\hline $\begin{array}{l}\text { Overall } \\
\text { mean }\end{array}$ & & $203,6 \mathrm{~cm}$ & $89.9 \mathrm{~cm}$ & $17.7 \mathrm{~mm}$ & 12 & $0.34 m^{2}$ & $14.74 \mathrm{~cm}$ & 7 & $255.7 \mathrm{~g}$ & $162.9 \mathrm{~g}$ & $7.1 \mathrm{e}^{4} \mathrm{~g}$ \\
\hline
\end{tabular}

$\mathrm{SV}=$ source of variation; $\mathrm{DF}=$ degree of freedom; $\mathrm{PH}=$ plant height; $\mathrm{FEIH}=$ first-ear insertion height; $\mathrm{SD}$ = stem diameter; $\mathrm{NF}=$ number of leaves; $\mathrm{LA}=$ leaf area; INL = internode length; NIN = number of internodes; SDB = stem dry biomass; LFB $=$ leaf dry biomass; TDB $=$ total dry biomass. ${ }^{* *},{ }^{*},{ }^{\text {ns }}$ Significant at $1 \%, 5 \%$ and not significant, respectively; (1), (2) and (3) Data transformed into $\frac{x^{1.389}-1}{1.389} ; \frac{x^{1.7424}-1}{1.7424}$ and $\frac{x^{2.3989}-1}{2.3989}$, respectively.

Plant height increased with the use of biochar, which provided higher means than control treatment at all rates applied. Regression analysis revealed that there was an increase in the height of maize up to the rate of $7.9 \mathrm{t} \mathrm{ha}^{-1}(219.2 \mathrm{~cm})$, whereas control treatment resulted in the lowest height (170.6 $\mathrm{cm}$ ) (Figure 1A). Also with regard to plant height, the highest mean in this study $(219.2 \mathrm{~cm})$ was higher than the $197 \mathrm{~cm}$ reported by Neves et al. (2015) in hybrid BRS 2022. This hybrid was fertilized at sowing with $150 \mathrm{~kg} \mathrm{ha}^{-1}$ ammonium sulfate, $450 \mathrm{~kg} \mathrm{ha}^{-1}$ triple superphosphate and $100 \mathrm{~kg} \mathrm{ha}^{-1}$ potassium chloride and topdressed with $150 \mathrm{~kg} \mathrm{ha}^{-1}$ ammonium sulfate at 30 and 60 days after plant emergence, which correspond to vegetative phases V3 and V6, respectively.

First-ear insertion height increased linearly, at a rate of $2.6 \mathrm{~cm}$ per ton of biochar applied to the soil, with the greatest height
$(103.3 \mathrm{~cm})$ reached with the application of 10.1 $\mathrm{t} \mathrm{ha}^{-1}$ of this substrate (Figure 1B). This height was $54.2 \%$ greater than the $67 \mathrm{~cm}$ obtained by Neves et al. (2015). Although plants with a higher insertion of the first ear are more prone to lodging, this event did not occur in the present study.

The greater plant height and firstear insertion height obtained with the use of biochar suggest that it provides nutrients for the maize crop, including $P(40.8 \mathrm{~g} \mathrm{~kg}-1)$. Saldanha, Rocha, Araújo and Alves (2017) also observed an increase in plant height with the supply of P. It is known that the amount of phosphorus absorbed influences shoot development, since it is a function of $\mathrm{P}$ in the plant as part of the adenosine triphosphate (ATP) molecule, acting in the storage and transfer of chemical energy captured from sunlight in photosynthesis (Saldanha et al., 2017). 

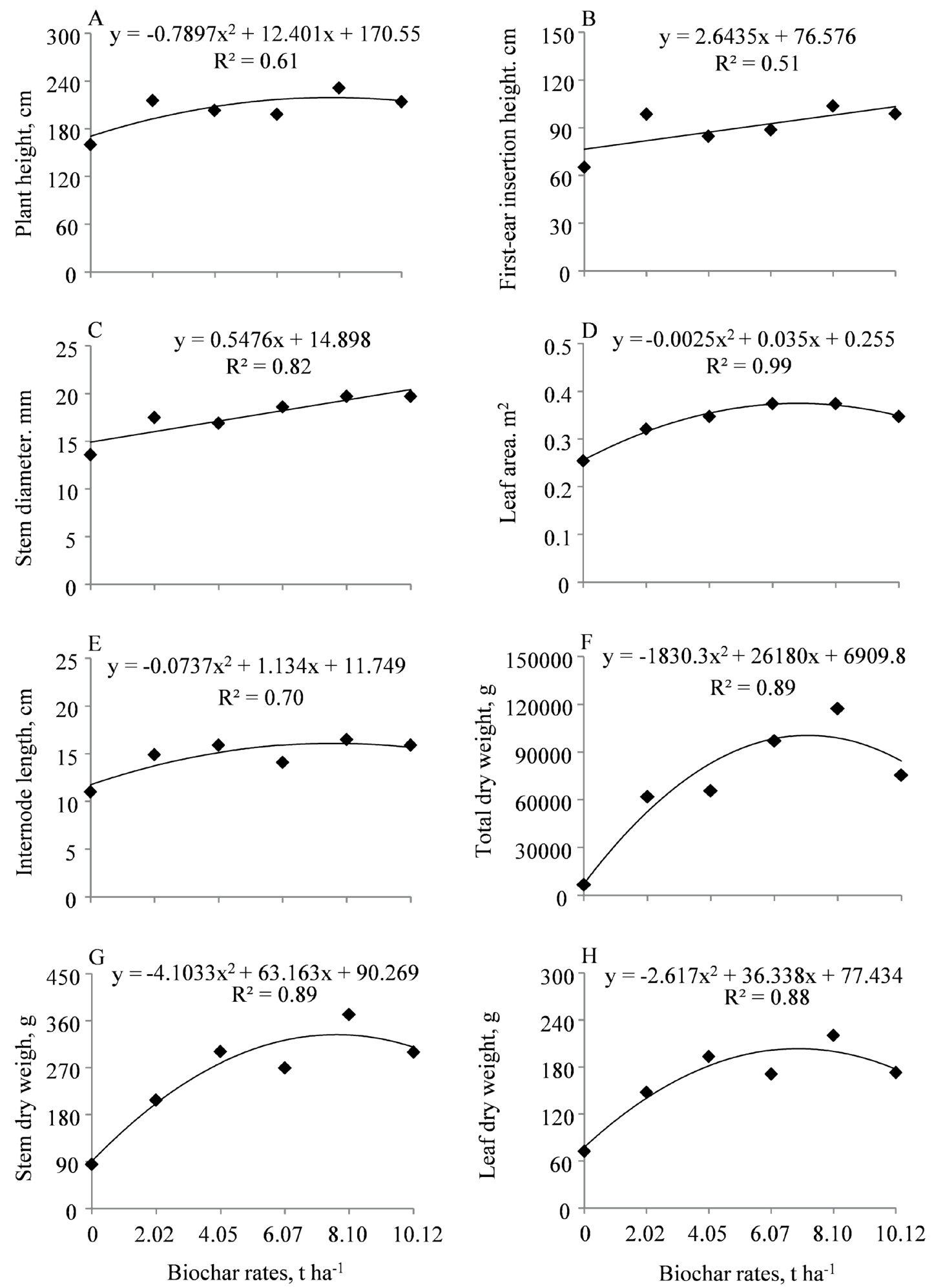

Figure 1. Plant height (A), first-ear insertion height (B), stem diameter (C), leaf area (D), internode length $(E)$, total dry weight (stems + leaves + ears) $(F)$, stem dry weight $(G)$ and leaf dry weight $(H)$ per plant according to biochar rates in BRS 2022 maize plants. 
Like first-ear insertion height, the stem diameter values fitted the linear regression model. This variable increased by $0.55 \mathrm{~mm}$ per ton of biochar applied to the soil, and the highest mean, $20.4 \mathrm{~mm}$, was obtained at the rate of $10.1 \mathrm{t} \mathrm{ha}^{-1}$ (Figure $1 \mathrm{C}$ ). When compared with the control treatment, the highest biochar rate provided a $37.2 \%$ increase in stem diameter. This result is promising, since the stem is a reserve structure that allows the translocation of photoassimilates to the grains (Fabrini, Silva, \& Rezende, 2021). According to Fagbenro, Oshunsanya and Onawumi (2013), the application of wood sawdust biochar in the production of moringa (Moringa oleifera) seedlings significantly influenced the stem diameter of these seedlings.

The largest leaf area (LA) of maize was $0.375 \mathrm{~m}^{2}$, which was obtained with $6.9 \mathrm{t} \mathrm{ha}^{-1}$ of biochar (Figure 1D). This result corroborates the data described by Situmeang, Adnyana, Subadiyasa and Merit (2015), who used bamboo biochar, composed of cow dung and a mineral fertilizer $(15 \% \mathrm{~N}, 15 \% \mathrm{P}$ and $15 \% \mathrm{~K})$ in maize growth and found a larger average $L A$ when biochar was applied at the rates of 5 and 10 t ha $^{-1}$.

The significant increase in LA indicates greater growth of the maize plants. The positive correlation between plant architecture and leaf area results in better use of photosynthetically active radiation, since the easier the access and the larger the flat leaf blades, the greater the ability of the plant to capture light and produce photoassimilates, which will later be distributed among the plant organs (Takasu, Rodrigues, Goes, \& Kaneko, 2019).

The greatest internode length $(16.1 \mathrm{~cm})$ was found with the application of $7.7 \mathrm{t} \mathrm{ha}^{-1}$ of biochar (Figure 1E). This result was higher than the $10.5 \mathrm{~cm}$ reported by J. S. M. Islam, Mannan, Khaliq and Rahman (2018) at 75 days after sowing, using maize hybrid BARI-9 fertilized with $7.0 \mathrm{t} \mathrm{ha}^{-1}$ of rice husk biochar. However, it is important to emphasize that in the present study, internode length was evaluated at 83 days after sowing.

In general, plants with longer internodes are more susceptible to lodging (plant arching dueto stembending) orbreakage. Nonetheless, although biochar increases internode length, this behavior was not observed in this study. Plants that have a strong stem are at a lower risk of lodging (Robertson, Lee, Julias and Cook, 2016), so improving the strength of the maize stem especially against the bending of the basal internodes is essential to reduce the risk of lodging and increase grain yield.

The biochar rates induced a quadratic increase in total dry biomass (Figure 1F), whose maximum value was $175.3 \mathrm{~g} \mathrm{plant}^{-1}$ (corresponding to $100,527.3 \mathrm{~g}$ plant $^{-1}$, transformed data), at $7.2 \mathrm{t} \mathrm{ha}^{-1}$ of biochar. The increase in production between control and the rate of $7.2 \mathrm{t} \mathrm{ha}^{-1}$ was equivalent to $339.8 \%$ (non-transformed data). Considering that the plants were harvested with a moisture percentage of $70 \%$, the highest total fresh matter would correspond to $573.5 \mathrm{~g} \mathrm{plant}^{-1}$ (non-transformed data).

Stem dry biomass increased with the biochar rates, with the highest mean, 83.1 g plant ${ }^{-1}$ (333.3 g plant $^{-1}$, transformed data), achieved at the rate of $7.7 \mathrm{t} \mathrm{ha}^{-1}$. (Figure 1G). Leaf dry biomass showed the same response, with the highest mean, $29.1 \mathrm{~g} \mathrm{plant}^{-1}$ (203.6 g plant $^{-1}$, transformed data), provided by the use of $6.9 \mathrm{t} \mathrm{ha}^{-1}$ of biochar (Figure 1H). Faloyea, Alatise, Ajayi and Ewulo (2017) also found significant effects of biochar addition on 
biomass, with the rate of $10 \mathrm{t} \mathrm{ha}^{-1}$ increasing the total biomass yield of maize by $62 \%$ as compared with the control treatment.

The higher biomass yields and growth of maize with the use of biochar are related to the nutrients present in it and, probably, to the presence of humic substances originating from its decomposition, which have hormonal properties that stimulate plant growth and improve yield (Fagbenro et al., 2013). The availability of nutrients in biochar particularly the phosphorus and potassium elements is evidenced by the responses shown by the growth and yield parameters of maize seen in this study. These elements are essential for the initial development of the plant, with $\mathrm{P}$ being of great importance for root growth, whereas $\mathrm{K}$, despite not constituting any organic molecule in the plant, is important for increasing stem thickness, activating enzymes and controlling the fluid flow in the plant (Freitas, Oliveira, Pinto, Cecon, \& Galvão, 2004).

Poultry litter biochar influenced the development of maize; however, it should be stressed that the effects of the application of this biochar on crop yield are complex and vary according to several factors, e.g. properties of the biochar raw material, rate of application, soil properties, climate, crop responses and management practices.

With respect to ear production, regardless of the biochar rate applied, only one ear was harvested per plant. In contrast, ear weight increased significantly with the use of biochar (Table 2), with the highest weight, $68.2 \mathrm{~g}$, achieved with the use of $6.6 \mathrm{t} \mathrm{ha}^{-1}$, which represented a $363.2 \%$ increase when compared with the control treatment (Figure 2A).

\section{Table 2}

Summary of analysis of variance for the production parameters of BRS 2022 maize according to different biochar rates

\begin{tabular}{|c|c|c|c|c|c|c|}
\hline \multirow{2}{*}{$\begin{array}{l}\text { Source of } \\
\text { variation }\end{array}$} & \multirow{2}{*}{$\begin{array}{l}\text { Degrees of } \\
\text { freedom }\end{array}$} & \multicolumn{5}{|c|}{ Mean square } \\
\hline & & EW & $\mathrm{GW}^{(1)}$ & $1000 \mathrm{~W}$ & $\overline{E L}$ & ED \\
\hline Rate & 5 & $2156.64^{* *}$ & $14.22^{\star *}$ & $4810.99^{* *}$ & $10.07^{* *}$ & $271.06^{* *}$ \\
\hline Linear & 1 & $4036.71^{* *}$ & $20.57^{* *}$ & $8146.61^{* *}$ & $17.02^{* *}$ & $543.12^{* *}$ \\
\hline Quadratic & 1 & $3819.59^{* *}$ & $15.02^{* *}$ & $13870.16^{* *}$ & $12.29^{*}$ & $451.30^{* *}$ \\
\hline Deviation & 3 & $975.63^{* *}$ & $11.84^{* *}$ & $679.40^{\text {ns }}$ & $7.01^{*}$ & $120.30^{* *}$ \\
\hline Error & 18 & 106.56 & 1.12 & 790.73 & 1.72 & 23.08 \\
\hline \multicolumn{2}{|c|}{ CV (\%) } & 20.41 & 26.88 & 36.29 & 12.20 & 16.38 \\
\hline \multicolumn{2}{|c|}{ Overall mean } & $50.57 \mathrm{~g}$ & $3.95 \mathrm{~g}$ & $77.49 \mathrm{~g}$ & $10.79 \mathrm{~cm}$ & $29.34 \mathrm{~mm}$ \\
\hline
\end{tabular}

Ear weight (EW), grain weight per plant (GW), 1000-grain weight (1000W), ear length (EL) and ear diameter (ED), ** * ns Significant at $1 \%$ and $5 \%$ probability and not significant, respectively; ${ }^{(1)} \sqrt{x}$ transformed data. 
Grain weight per ear responded similarly to ear weight, with the highest mean, $26.0 \mathrm{~g}$ (non-transformed data), achieved with the use of $6.6 \mathrm{t} \mathrm{ha}^{-1}$ (Figure 2B). By comparing this yield with the $2.4 \mathrm{~g}$ obtained in the absence of biochar (non-transformed data), we found that this input increased it by $1006.8 \%$. Stipulating grain yield for field conditions and considering a spacing of $1 \mathrm{~m}$ between rows with five plants per linear meter, grain yield would be only $1.3 \mathrm{t} \mathrm{ha}^{-1}$, which is well below the 5.5 and 10.3 t ha $^{-1}$ obtained by J. S. M. Islam et al. (2018) with the rice husk biochar rates of 0 and 7 t ha $^{-1}$, respectively.

As also illustrated in Figure $2 \mathrm{~B}$, the fit of the grain-weight means to the quadratic regression model suggests that the decrease in yield at rates above $6.59 \mathrm{t} \mathrm{ha}^{-1}$ may be associated with various reasons. One of them is the presence of basic cations in biochar, which increased the soil base saturation (after incubation) to $87 \%$ with the application of the highest rate $\left(10.12 \mathrm{t} \mathrm{ha}^{-1}\right)$. It is noteworthy that the increase in base saturation was mainly due to the contribution of $\mathrm{K}$ and $\mathrm{Na}$ and that the recommended base saturation for the maize monoculture is 65\% (Brito, Pereira, \& Brachtvogel, 2019). The increase in soil fertility with applications of biochar amounts larger than $6.6 \mathrm{t} \mathrm{ha}^{-1}$ likely caused imbalance and damage to the plant metabolism, interfering with the biochemical processes that occur in it. With metabolism affected, vital functions were impaired and the damage resulted in decreased grain yield.

Despite not being presented in this study, the number of grain rows per ear was crucial for grain yield, because with the exception of ears produced with $6.1 \mathrm{t} \mathrm{ha}^{-1}$ of biochar, the others exhibited low grain filling. Although nitrogen fertilization was split into three applications, the high potassium concentration may have reduced the nitrogen availability for the plant, which negatively affected the number of grains per ear and ear weight.

Another important factor that may also have contributed to the low grain yield in this study was incubation time, i.e., planting took place three days after the application of biochar to the soil. Major, Rondon, Molina, Riha and Lehmann (2010) analyzed the yield and nutrition of maize fertilized with biochar for four years and did not observe a significant effect on crop yield in the first year. Nevertheless, in subsequent years, the yield of maize increased with the increasing rates of biochar applied, demonstrating residual effects favorable to crop yield.

Biochar is known to influence many soil characteristics, e.g., color, cationexchange capacity, nutrient content (macro and micronutrients), aeration, among others; however, because it is organic, its decomposition time, through microbial activity, should be considered. According to some authors, at first, microorganisms function as soil conditioners, with biochar acting as a catalyst, which would explain the increase in the yield of maize in the years subsequent to the application of biochar. Such increases in yield have already been described to last up to three years after the application of biochar from organic waste (T. Islami, Kurniawan, \& Utomo, 2013). Thousand-grain weight was significantly influenced by the biochar rates (Table 2 ) and the highest yield (108.63 g) was achieved with the application of $6.2 \mathrm{t} \mathrm{ha}^{-1}$ (Figure 2C). 

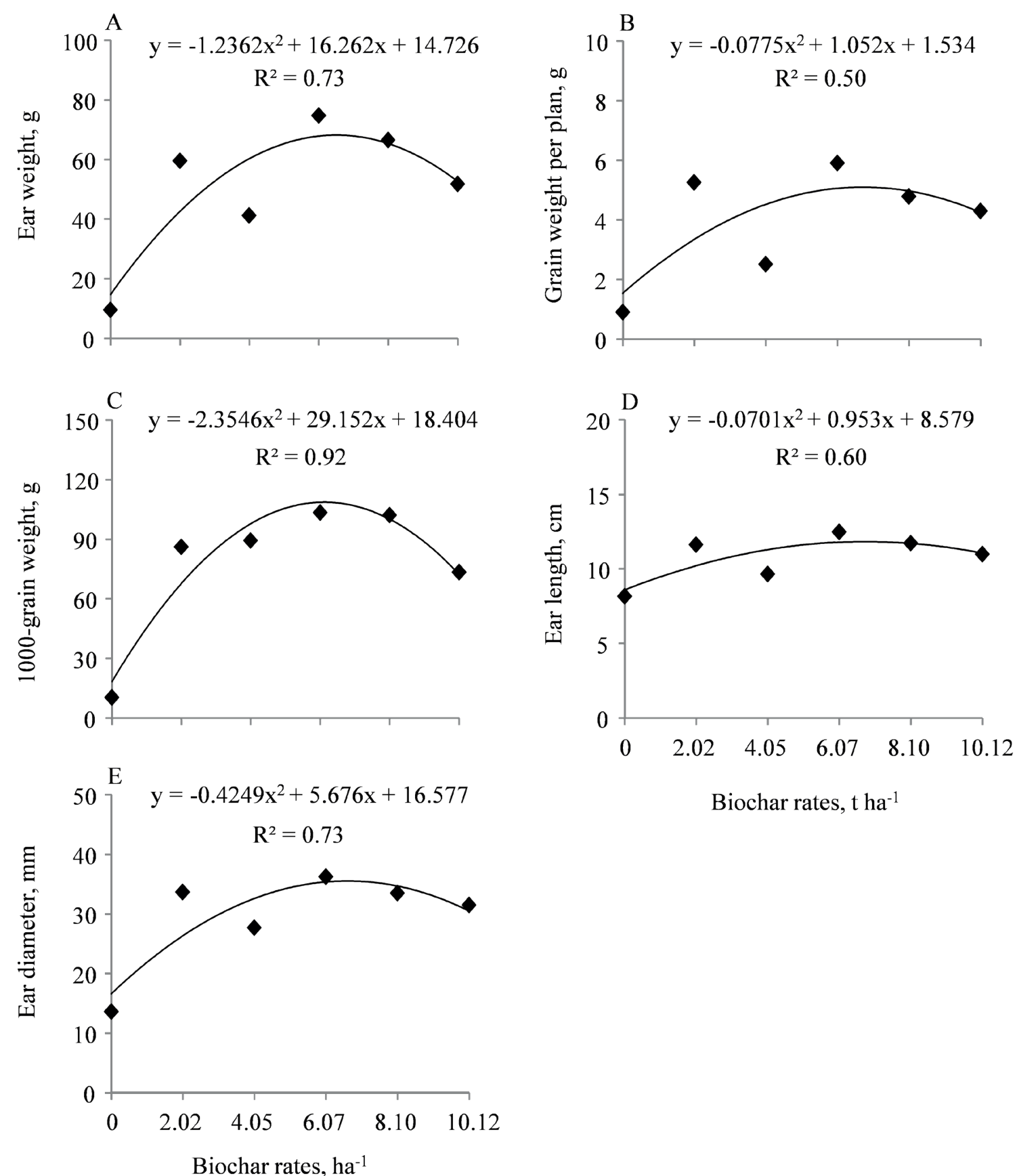

Biochar rates, $\mathrm{t} \mathrm{ha}^{-1}$

Figure 2. Ear weight (A), grain weight per plant (B), 1000-grain weight (C), length (D) and ear diameter (E) according to biochar rates applied to BRS 2022 maize. 
Ear length and diameter reached their highest values $(11.8 \mathrm{~cm}$ and $35.5 \mathrm{~mm}$ ) with the application of 6.8 and $6.7 \mathrm{t} \mathrm{ha}^{-1}$ of biochar, respectively (Figures $2 \mathrm{D}$ and $2 \mathrm{E}$ ), and the lowest means were obtained with control treatment (without biochar). Ear length is directly linked to the yield potential of maize, as larger ears may have a higher number of grains in the row. Lager ears are associated with higher yield in maize plants, as this trait influences grain weight.

In a study on the impact of rice husk biochar on maize yield, Shashi, Mannan, Islam and Rahman (2018) obtained the highest 100-grain weight, ear length and ear diameter (27.7 g, $17.7 \mathrm{~cm}$ and $39.0 \mathrm{~mm}$, respectively) with the application of $20 \mathrm{t} \mathrm{ha}^{-1}$ and a water regime of $80 \%$ of field capacity.

\section{Conclusions}

The application of increasing rates of poultry litter biochar in the growth of maize hybrid BRS 2022 influenced agronomic performance, that is, plant height, first-ear insertion height, stem diameter, leaf area, internode length, stem dry biomass, leaf dry biomass and total dry biomass. Likewise, it had a positive influence in increasing all production variables analyzed (ear weight, grain weight per plant, 1000-grain weight, ear length and ear diameter). Overall, poultry litter biochar has the potential to increase the yield of maize in a dystric Gray Ultisol. The biochar rate used and, therefore, recommended to achieve the best results in this study corresponds to an application of $6.4 \mathrm{t} \mathrm{ha}^{-1}$ of this input.

\section{Acknowledgments}

Thanks are extended to the National Council for Scientific and Technological Development (CNPq) for the Senior PostDoctoral Fellowship grant (Bolsa de PósDoutorado Sênior, PDS) awarded to the third and fourth authors.

\section{References}

Agboola, K., \& Moses, S. A. (2015). Effect of biochar and cow dung on nodulation, growth, and yield of soybean (Glycine max I. Merrill). International Journal of Agriculture and Biosciences, 4(4), 154160. http://www.ijagbio.com/pdf-files/ volume-4-no-4-2015/154-160.pdf

Biederman, L. A., \& Harpole,W.S. (2013). Biochar and its effects on plant productivity and nutrient cycling: A meta-analysis. GCB Bioenergy, 5(2), 202-214. doi: 10.1111/ gcbb. 12037

Brito, A. R., Pereira, H. S., \& Brachtvogel, E. L. (2019). Saturação por bases na integração lavoura-pecuária com cultivo de milho nos dois primeiros anos. Colloquium Agrariae, 15(3), 58-68. doi: 10.5747/ca. 2019.v15.n3.a299

Chaves, L. H. G., Fernandes, J. D., Dantas, E. R. B., Guerra, H. C., Tito, G. A., Silva, A. A. R.,... Chaves, I. B. (2020). Characterization of poultry litter biochar for agricultural use. Sylwan, 164(6), 468-487.

Fabrini, D. F., Silva, M. C. P., \& Rezende, C. F. A. (2021). Development and productivity of maize submitted to the nitrogen installment in coverage. Ipê Agronomic Journal, 5(1), 1-9. doi: 10.37951/259 5-6906.2021v5i1.6524 
Fagbenro, J. A., Oshunsanya, S. O., \& Onawumi, O. A. (2013). Effect of saw dust biochar and NPK 15:15:15 inorganic fertilizer on Moringa oleifera seedlings grown in an Oxisol. Agrosearch, 13(1), 57-68. doi: 10. 4314/agrosh.v13i1.6

Faloyea, O. T., Alatise, M. O., Ajayi, A. E., \& Ewulo, B. S. (2017). Synergistic effects of biochar and inorganic fertiliser on maize (Zea mays) yield in an Alfisol under drip irrigation. Soil and Tillage Research, 174(10), 214-220. doi: 10.1016/j.still.2017.07.013

Fernandes, B. C. C., Mendes, K. F., Dias, A. F., Jr., Caldeira, V. P. S., Teófilo, T. M. S., Silva, T. S.,... Silva, D. V. (2020). Impact of pyrolysis temperature on the properties of eucalyptus wood-derived biochar. Materials, 13(24), 1-13. doi: 10.3390/ ma13245841

Ferreira, D. F. (2011). Sisvar: a computer statistical analysis system. Ciência Agronômica, 35(6), 1039-1042. doi: 10.1590/S1413-70542011000600001

Freitas, W. S., Oliveira, R. A., Pinto, F. A., Cecon, P. R., \& Galvão, J. C. C. (2004). Efeito da aplicação de águas residuárias de suinocultura sobre a produção do milho para silagem. Revista Brasileira de Engenharia Agrícola e Ambiental, 8(1), 120-125. doi: 10.1590/S1415-43 662004000100018

Furtado, G. F., \& Chaves, L. H. G. (2018). Growth rates and sunflower production in function of fertilization with biochar and NPK. Journal of Agricultural Science, 10(2), 260-270. doi: 10.5539/jas.v10n2p260

Islam, J. S. M., Mannan, M. A., Khaliq, Q. A., \& Rahman, M. M. (2018). Growth and yield response of maize to rice husk biochar.
Australian Journal of Crop Science, 12(12), 1813-1819. doi: 10.21475/ajcs. 18.12.12p944

Islami, T., Kurniawan, S., \& Utomo, W. H. (2013). Yield stability of Cassava (Manihot esculenta Crantz) planted in intercropping systemafter $3 y e a r s$ of biochar application. American Eurasian Journal of Sustainable Agriculture, 7(4), 306-312.

Liu, X., Zhang, A., Ji, C., Joseph, S., Bian, R., Li, L., Pan, G., \& Paz-Ferreiro, J. (2013). Biochar's effect on crop productivity and the dependence on experimental conditions-A meta-analysis of literature data. Plant and Soil, 373, 583-594. doi: 10.1007/s11104-013-1806-x

Major, J., Rondon, M., Molina, D., Riha, S. J., \& Lehmann, J. (2010). Maize yield and nutrition during 4 years after biochar application to Colombian savanna oxisol. Plant and Soil, 333, 117-128. doi: 10. 1007/s11104-010-0327-0

Masud, M. M., Abdulaha-AlBaquy, M., Akhter, S., Sen, R., Barman, A., \& Khatun, M. R. (2020). Liming effects of poultry litter derived biochar on soil acidity amelioration and maize growth. Ecotoxicology and Environmental Safety, 202(1), 1-10. doi: 10.1016/j.ecoenv.2020.110865

Mendes, J. S., Fernandes, J. D., Chaves, L. H. G., Guerra, H. O. C., Tito, G. A., \& Chaves, I. B. (2021). Chemical and physical changes of soil amended with biochar. Water Air, \& Soil Pollution, 232(8), 1-13. doi: 10.1007/ s11270-021-05289-8

Neves, A. L. A., Santos, R. D., Pereira, L. G. R., Tabosa, J. N., Albuquerque, I. R. R., Neves, A. L. A.,... Verneque, R. S. (2015). Agronomic characteristics of corn cultivars for 
silage production. Semina: Ciências Agrárias, 36(3), 1799-1806. doi: 10.5433/ 1679-0359.2015v36n3Supl1p1799

Pacheco, C. A. P., Parentoni, S., Netto, Guimarães, P.E. O., Gama, E. E. G., Meirelles, W. F., Ferreira, A. S.,... Costa, R. V. (2009). BRS 2022: híbrido duplo de milho. Sete Lagoas, MG: EMBRAPA Milho e Sorgo.

Pissinati, A., Oliveira, M. A., Pissinati, A., \& Moreira, A. (2013). Management and cost of urea application in maize grown in northern Paraná state, Brazil. Revista de Ciências Agrárias, 56(3), 235-241. doi: 10. 4322/rca.2013.034

Revell, K. T., Maguire, R. O., \& Agblevor, F. A. (2012). Influence of poultry litter biochar on soil properties and plant growth. Soil Science, 177(6), 402-408. doi: 10.1097/ SS.0b013e3182564202

Robertson, D. J., Lee, S. Y., Julias, M., \& Cook, D. D. (2016). Maize stalk lodging: flexural stiness predicts strength. Crop Science, 56(4), 1711-1718. doi: 10.2135/ cropsci2015.11.0665

Saldanha, E. C. M., Rocha, M. E. L., Araújo, J. L. S., \& Alves, J. D. N. (2017). Adubação fosfatada na cultura do milho no nordeste paraense. Revista de Ciências Agroveterinárias, 16(4), 441-448. doi: 10. 5965/223811711642017441

Shashi, M. A., Mannan, M. A., Islam, M. M., \& Rahman, M. M. (2018). Impact of rice husk biochar on growth, water relations and yield of maize (Zea mays L.) under drought condition. The Agriculturists, 16(2), 93101. doi: 10.3329/agric.v16i02.40347
Situmeang, Y. P., Adnyana, I. M., Subadiyasa, I. N. N., \& Merit, I. N. (2015). Effect of dose biochar bamboo, compost, and phonska on growth of maize (Zea mays L.) in Dryland. International Journal on Advanced Science, Engineering and Information Technology, 5(6), 433-439. doi: 10.18517/ijaseit.5.6.609

Spokas, K. A., Novak, J. M., Stewart, C. E., Cantrell, K. B., Uchimiya, M., DuSaire, M. G., \& Ro, K. S. (2011). Qualitative analysis of volatile organic compounds on biochar. Chemosphere, 85(5), 869-882. doi: 10. 1016/j.chemosphere.2011.06.108

Takasu, A. T., Rodrigues, R. A. F., Goes, R. J., \& Kaneko, F. H. (2019). Interceptação da radiação solar e área foliar do milho influenciada pelo arranjo espacial de plantas. In R. R. S. Silva-Matos, N. A. F. Machado, \& M. R. L. Leite (Orgs.), Desafios e perspectivas do plantio direto (pp. 2837). Ponta Grossa, PR: Atena.

Teixeira, P. C., Donagemma, G. K., Fontana, A., \& Teixeira, W. G. (2017). Manual de métodos de análise de solo (3a ed. rev. e ampl.). Brasília, DF: EMBRAPA.

Tito, G. A., Fernandes, J. D., Chaves, L. H. G., Guerra, H. O. C., \& Dantas, E. R. B. (2021). Organic carbon mineralization of the biochar and organic compost of poultry litter in an Argisol. Semina: Ciências Agrárias, 42(6), 3167-3184. doi: 10.5433/1679-0359.2021v42n6p3167

Tomczyk, A., Sokołowska,Z., \&Boguta, P. (2020). Biochar physicochemical properties: pyrolysis temperatureand feedstock kind effects. Reviews in Environmental Science and Bio/Technology, 19(3), 191-215. doi: 10.1007/s11157-020-09523-3 
